\title{
Federalism and political theory: a case of mutual neglect?
}

\section{Thomas O. Hueglin}

For most people, federalism simply is a form of divided government. Examinations of this form typically revolve around a set of definitional characteristics such as a constitutional division of powers, legislative bicameralism, and intergovernmental relations. Explanatory theories examine the operation (Riker 1964), robustness (Bednar 2009), or effectiveness (Bakvis and Skogstad 2012) of federalism as defined this way. The study of federalism, by and large, can be characterized as the investigation into a particular set of institutions and procedural mechanisms, the legitimacy of which is evaluated by systemic performance criteria.

Far less typical are normative investigations about how federalism relates to "larger principles of justice and . . civic purposes" (Elazar 1987: 1). Such investigations are often rejected outright with the assertion that there is no inherent value in federalism (Neumann 1955). If at all, theories of federalism with a normative bent are culled from the history of political thought (Karmis and Norman 2005; Ward and Ward 2009). From these author- or country-specific approaches, the idea of federalism emerges as a broad church of ideas and concepts, ranging from the ancient Jewish covenant (Elazar and Kincaid 200o) to "de facto federalism" in China (Zheng 2007). Absent a more clearly defined understanding of federalism as a normative proposition, political philosophy does not often take notice of it (Weinstock 2001). An authoritative handbook on political theory does not mention it at all (Dryzek et al. 2006).

The uneasy relationship between federalism and political theory finally stems from the fact that the idea of a political order described as "self-rule and shared rule" (Elazar 1987: 5) does not fit easily into concepts of modern rationality. Ever since Descartes postulated that "there is only one truth concerning any matter" (Descartes 1637 [1985]: 121), modern political thought and theory have been in the thrall of monistic or universalist approaches to political organization. Jean Bodin (1583 [1992]) and Thomas Hobbes (1651 [1991]) declared sovereignty to be indivisible and absolute, Jean-Jacques Rousseau (1762 [1968]) attributed sovereignty to a nebulous general will, and nineteenth-century industrial capitalism sought to create sovereign nation-states in which market relations would no longer be hampered by a plurality of rules, norms and languages. Federalism inevitably remained undertheorized as a legitimate political order because its complicated rules of divided powers could not be seen as more than a second-best if not outright "tragic" compromise (Feeley and Rubin 2008). 
It would seem, then, that there should be plenty of room for an extended and reinvigorated research agenda focusing on the normative values inherent in the idea of federalism. Based on earlier comparative work (Hueglin and Fenna 2015), I propose identity, autonomy, equality and solidarity as such values.

\section{Territorial identity}

With John Locke's declaration that a commonwealth is created when "any number of Men have so consented to make one Community or Government" (1691, II: 95) begins the ascendance of individual liberalism as Western political theory's dominant paradigm. This has been nowhere more so than in the United States of America-so much so that the late Daniel J. Elazar noted with some degree of frustration: "Americans have a very difficult time understanding the issues of group rights" (1987: 95). Group rights on the basis of territorial identity, however, lie at the heart of the federalist creed. Federalism in this way connects with one of the most profound questions of political theory: whether the identity of human beings is independent of sociopolitical memberships (Rawls 1971) or is embedded in such memberships and the shared communal practices they provide (Sandel 1982). Normative justifications of federalism typically assume that human beings are naturally inclined to organize social life in a plurality of smaller and larger communities with shared beliefs and practices. Federalism in this sense is seen as a natural form of political organization: "All life is federalist in character" (Jerusalem 1949: 6-9; own transl.).

The problem is that federalism is almost exclusively understood as a territorial organization of plurality. ${ }^{1}$ This is explainable by the fact that the classical federations were formed in the eighteenth and nineteenth centuries and, hence, at a time when territoriality more strongly coincided with community. In modern mass societies with rapid access to communication and migration, this may no longer be true. For this reason, federalism has been questioned as a meaningful organization of plurality unless territorial boundaries continue to coincide with sociological difference (Erk 2008). Indeed, the possibilities of federalism as a legitimate territorial order are now mainly discussed in terms of cultural or ethnic accommodation (Basta et al. 2015).

The concept of territory itself is rarely discussed from a federalist perspective. A major "political theory of territory", for instance, seeks to justify authority over land, resources and borders as a moral claim to self-determination (Moore 2015). Yet it leaves little room for federalism as that quintessentially territorial form of "fairness", which not only seeks to accommodate the autonomy aspirations of territorial identity groups but also allows us to reconceptualize self-determination as simultaneous membership in plural communities (De Schutter 2011).

It is the sociological explanation in particular that invites us to rethink federalism and territorial identity. Following in the tradition of an old debate, this explanation 
claims that form follows function: federalism is an institutional response to territorial identities. In doing so, it explicitly seeks to refute institutionalist explanations of federalism, which are said to "hold identity to be a product of institutions" (Erk 2008: 11).

Territorially manifest ethnic or cultural difference may indeed be the most powerful driver for the problematique of what Stepan called "holding together federalism" (1999: 20). But the sociological approach not only underestimates the usefulness of historical-institutionalist analyses in explaining that part of the federal dynamic that is owed to a path-dependent institutional and procedural trajectory over time (Broschek 2013), it also neglects the possibility that this trajectory may itself produce a powerful sociological explanation of territorial legitimacy, namely, a political culture of federalism constituting overlapping territorial identities as an intrinsic federalist value. In doing so, the institutions and procedures of federalism may be theorized, not just as "mechanisms" enabling or constraining ideational predispositions of identity (Béland and Lecours 2013: 226), but as constitutive factors of a kind of territorial identity formation that can contribute to a more complex understanding of self-determination.

\section{Particular autonomy}

Against the backdrop of the Reformation, religious wars and the rise of the absolutist state, the first important theorist of federalism, Johannes Althusius, wrote at the start of the seventeenth century that in a composite commonwealth like the German Reich, a majority could decide matters that concern all members alike, but not matters that concern them separately (1614 [1995], VIII: 70). The problem of federalism ever since has been to determine what is common or universal, and what is separate or particular.

The designers of the classical eighteenth- and nineteenth-century federal states thought they had resolved the problem by means of a constitutional division of power, which essentially assigned to the national government those powers required for economic union, internal security and external defense, while leaving to the subnational governments what was considered to be of local significance, such as social policy matters, including welfare and education. The federated entities would thus remain autonomous in matters significant for their particular local cultures and collective identities.

The attempt to divide powers cleanly between two different orders of government proved problematic almost from the very beginning. Except for a few policy fields such as printing money or maintaining armed forces, it became entirely illusionary under conditions of complex governance in the twentieth and twenty-first centuries. Today, both orders of government in federal systems are simultaneously active in almost all policy fields. Short of litigation, this blurring of precise boundaries of autonomy inevitably requires some agreed-upon understanding of power sharing. 
In fact, it has been argued that federal constitutions are no more than "incomplete" contracts providing "basic rules" for an ongoing process of "intergovernmental contracting" (Rodden 2006: $37-8$ ), and that there is a trend from constitutional federalism to more procedural forms of "treaty" federalism (Hueglin 2013).

Nevertheless, an understanding of federalism persists according to which it somehow corresponds to a type of multilevel governance characterized as "minimizing interjurisdictional coordination" (Hooghe and Marks 2003: 241). This cannot really be surprising as long as nearly every conceptual treatment not only identifies a rigid constitutional division of powers as one of the hallmarks of federalism but also adheres to the long-debunked myth that directly elected second or regional chambers suffice as mechanisms for whatever degree of interjurisdictional coordination might be required (Riker 1955). It is here that conceptualizations of federalism need to rethink what territorial autonomy can possibly mean under complex conditions of overlapping powers, practices of power sharing and compromise.

To suggest that the principle of subsidiarity might offer a promising conceptual tool for such rethinking is no longer novel. Ever since it gained notoriety as a core principle of legitimate governance in the 1993 Maastricht Treaty of the European Union (e.g., Peterson 1996), theoretical interest in the nexus between federalism and subsidiarity has been in ascendance (e.g., Fleming and Levy 2014). Yet from the prevailing view of federalism as a form of political order primarily characterized by a constitutional division of powers, considerable skepticism remains as to the safeguards subsidiarity may offer for territorial autonomy (e.g., Brouillet 2011).

The skepticism has to do with the procedural nature of subsidiarity. In its simplest form, subsidiarity means that decisions should be taken at the lowest level of government possible, or, as enshrined in Article 1 of the Treaty on European Union, "as closely as possible to the citizen". What that exactly means, what in other words should be universal and what should be particular, ultimately can only be decided from case to case by means of negotiated agreement. This is how subsidiarity considerations differ from constitutional power divisions. From the perspective of territorial autonomy, however, the reliance on agreement does not appear to offer the same safeguards as legal certainty, even when that certainty may come to light only through judicial interpretation with uncertain outcomes. Yet it is precisely this procedural nature of subsidiarity that invites us to rethink particular autonomy in the context of federalism.

When Hobbes first pre-formulated modern social contract theory, he declared that the outcome of the covenant must be "more than Consent, or Concord; it is a real Unitie" (1651 [1991], XVII (87): 120). This meant the elimination of any procedural or deliberative element in politics, which Hobbes saw as the source of conflict. Modern constitutional federalism differs from the Hobbesian commonwealth in its division of powers, but except for the deliberately difficult process of constitutional 
change, the constitutional finality of this division seeks to follow Hobbes's prescription in its attempt to eliminate procedural uncertainty.

Hobbes broke with all previous tradition, particularly with the "erroneous Philosophy of the Greeks, especially of Aristotle" (1651, XLIV (334): 418). Not only had Aristotle famously defined man as naturally forming and living in political communities-zoon politikon (1962: 1253a1), he had also discussed a well-constituted polity as a mixed regime of oligarchy and democracy (1962: 1293b22-1294b41). "A feast to which all contribute", he declared, "is better than one supplied at one man's expense" (1962: 1281a39). Such a feast, it seems obvious, requires negotiated cooperation and coordination.

Writing some forty years before Hobbes, Althusius tried to stem the tide of absolutism by summing up the entire tradition that his English counterpart rejected so vehemently. Specifically referring to Aristotle, and drawing from the quasi-federal institutions and processes of the Holy Roman Empire, Althusius made "mutual communication" the procedural center-piece of a theory of federalism in which power would be shared among a plurality of smaller and larger political communities (1614 [1995], I: 7; Hueglin 1999). Unity would require consent among what Pierre-Joseph Proudhon some 250 years later called "a plenitude of autonomies" (1863 [1979]: 40). The European Union still is committed to this procedural principle of governance by communicative deliberation (Neyer 2003) in which, with explicit reference to Althusius, "no-one is the exclusive holder of public authority" (Amato 2002: 577-81).

What would appear to merit further theoretical reflection, then, is how federalism comprises an ideational understanding of particular autonomy bounded in the universality of a common enterprise; how such particular autonomy requires a commitment to a kind of communicative action within that common enterprise that must be able to rise above the systemic constraints of the constitutional form without violating its covenanted foundation (Habermas 1991); and how federalism in this sense can be understood as a "dialogical" form of political legitimacy situating autonomy in the "in-between" of the universal and the particular (Lindahl 2008).

There is room, in other words, for a theoretical repositioning of federalism that moves away from its classical understanding of autonomy as "non-interference", and toward what the late Iris Marion Young called self-determination as "relational autonomy or non-domination" (cited in Levy 2008: 62-3). As Levy suggests, this necessarily implies "treating self-determination and shared decision making as compatible" (2008: 76). The obvious objection to such an understanding of federalism is that it opens conflicts over precisely the question the designers of modern constitutional federalism sought to avoid: when does interference become domination? However, the assumption that constitutionalizing non-interference can avoid such conflicts has been an illusion in modern federalism all along. 


\section{Membership equality}

A core principle of federalism is membership equality. The constituent members of a federation enter into a common union with the expectation to be treated equally regardless of their strength and size. Most other forms of multilevel governance, from ancient leagues to modern trade associations, are governed by a different principle and rationale. As the Athenians famously explained to the Melians: "The strong do what they can and the weak suffer what they must" (Thucydides 1934, $\mathrm{V}: 17)$.

The idea of membership equality is commonly traced to the American compromise of 1787, "compound majoritarianism" (Elazar 1987: 19) in a bicameral legislature with proportional representation in the House of Representatives favoring the large states, and equal representation of the states with two senators each in the Senate. James Madison called the Senate the embodiment of the federal principle (The Federalist, No. 39). While some federations such as Switzerland and Brazil followed the American example of formal membership equality in second legislative chambers, others such as Germany adopted a system of weighted second-chamber representation, balancing membership equality with population size.

In either case, though, considerations of decision-making efficiency outweigh-and are meant to outweigh-membership equality in a more existential sense. Such equality ultimately can be satisfied only by the same principle of unanimous agreement inherent in the original commitment to form a federal union. This is what Madison rejected as confederal "imbecility" (The Federalist, No. 20). He referred to the Netherlands, the same polity Althusius had praised as an example of consensusbased decision-making (1614 [1995], XXXIII: 20), and which still provided a point of departure for Lijphart's life-long investigations into the nature of consensusbased or consociational democracy (Lijphart 2012).

Summing up what by now would appear to be conventional wisdom, majority rule allows for efficient decision-making but majority decisions may be difficult to implement, particularly so in the presence of deep societal divisions. Reversely, unanimous agreement may be difficult to achieve in the presence of such divisions, but once achieved, will be easier and more efficient to implement. Lijphart goes further by claiming that consensus-based decision-making also results in "kinder, gentler" policy outcomes (2012: 274-94).

What deserves further theoretical reflection, then, is not only the perceived contradiction in federalism between the political legitimacy of federalism as derived from membership equality underwritten by consent, and the political efficiency of majoritarian decision-making, however compounded. One might also want to rethink the extent to which consent-based imbecility can turn into efficiency as Lijphart would suggest. Largely consent-based decision-making in the European Union, for instance, as Hall has pointed out, can point to a record of "making novel political arrangements work" through negotiated compromise (2013). 
In the context of membership equality, the question of symmetry versus asymmetry in federal systems might also benefit from further theoretical reflection. Inherent in the original federal agreement is the assumption of constitutionally guaranteed power equality for all constituent members. Why otherwise would these members agree to enter into a common union? Yet in practice, asymmetries exist in many federal systems. In quasi-federal Spain, for instance, the autonomous communities of the Basque Country and Navarra enjoy a higher degree of financial autonomy than other communities due to the recognition of historical charters.

These are de jure asymmetries as distinguished from de facto asymmetries that result when the members of a federation use equal powers in different ways. In Canada, de jure asymmetry was denied to the Francophone province of Quebec when its constitutional recognition as a "distinct society" failed over English Canadian concerns that such particular autonomy asymmetry was incompatible with the federal principle of provincial equality. According to the prevailing view in Quebec, however, "asymmetry is not merely compatible with the federal principle; it is intrinsic to federalism" (Pelletier 2012: 476).

Much useful work has been done on federalism and asymmetry (e.g., Agranoff 1999). Yet the discussion is often guided by instrumentalist rather than conceptual considerations. Asymmetry is seen as "Janus-faced" (Burgess 2006: 209) by simultaneously living up to the federal promise of accommodating difference and also providing power structures for disunity and even secession (Kymlicka 2005: 285-9). Missing is a sustained theoretical argument about whether and how the foundational federal principle of membership equality can be compatible with an $a$ priori form of de jure constitutional asymmetry recognizing a diversity of interests and needs among the members of a federal union that cannot be accommodated by the kind of de facto variability of policy arrangements and outcomes normal in all federal systems when the member units use their equal powers to different ends.

\section{Social solidarity}

By agreement, the constituent members of a federal union commit themselves to exercise their respective powers in ways meant to make maintenance of the union meaningful for all. The assignment of autonomous powers to the federation's members does not amount to much if the material means for exercising these powers are lacking. Inherent in the original agreement of membership equality, therefore, is a commitment to social solidarity in the sense that nobody is supposed to fall behind in a common enterprise, the entire purpose of which is the creation of, and sharing in, a common-wealth.

We can take the cue from Althusius again. He first transposed the Aristotelian assumption of the natural sociability of human beings into the organized relationship of a plurality of smaller and larger communities. As the overall purpose of the federal common-wealth resulting from this organized relationship, he identified 
"extending prompt assistance" to members "caught in distress and need" (1614 [1995], XVI: 2). For Althusius, federalism is a dialectical relationship between the autonomous right of self-governance in a plurality of smaller communities and a universal obligation to mutual sharing and aid.

The German constitution (Grundgesetz) explicitly empowers the federal government to legislate in certain areas of concurrent jurisdiction if that is necessary in order to achieve "equitable living conditions" across the entire federation (Article 72.2). The most obvious expression of mutual aid in federal systems is fiscal equalization. Under the Canadian Constitution Act of 1982, the federal government is "committed to the principle of making equalization payments to ensure that provincial governments have sufficient revenues to provide reasonably comparable levels of public services at reasonably comparable levels of taxation" (Article 36.2).

The question of the dialectical relationship between autonomy and mutual obligation is thus, for the most part, left to calculating public finance considerations about cost, need and the proportionality of revenue and expenditure (Blöchlinger and Charbit 2008). What remains undertheorized is how the principles of social solidarity and social justice that underwrite the idea of a federal union can be reconciled, or at least balanced, with market-oriented views of competitive federalism that emerged during the 1980 s with the rise of neoliberalism (Breton 1987). The price to be paid for too much emphasis on solidarity, these views allege, is the inefficient allocation of resources by an overbearing central government supplanting healthy interjurisdictional competition with regulation in the name of cooperation. If it is "not self-evident" that cooperative federalism of this kind is "uniformly superior" to competitive federalism, the theoretical as well as practical task at hand is indeed to find "safeguards" against the market-driven erosion of social solidarity and social justice as core values of federalism (Kincaid 1991: 111-12).

Such theorizing might take a fresh look at a much-neglected strand of federalist thought that had its beginnings in the so-called anarcho-federalism of Proudhon. It gained prominence during the years between World War I and World War II as an invitation to conceptualize a form of socio-political organization beyond capitalism and communism. It found its way into European resistance movements against the Nazis by contemplating a postwar project of a European federation as a peace order of mutual solidarity rather than a union for transborder profit maximization. It did play a brief, if futile, role in the discussions about European integration after 1945 (Hueglin and Fenna 2015: 94-7).

Proudhon left only an opaque sketch of what he meant by the federal principle (1863 [1979]), and his vision of a federation composed of autonomous producer and consumer cooperatives certainly falls into the realm of utopian socialist idealism. But Proudhon's vision later gave rise to what came to be known as a school of "integral federalism", arguing that "real" federalism could not just simply be political federalism but had to include all dimensions of socio-economic reproduction 
(Roemheld 1990). Most prominently associated with the names of Alexandre Marc (1979) and Denis de Rougemont (Tassin 1992), integral federalism was very much a response to the catastrophic crises of the first half of the twentieth century.

I am not proposing a research agenda on federalism as a radical theory of socialist transformation. However, theorizations of federalism committed to social solidarity might benefit from a rich body of thought that did not just see federation as a protective mechanism for group identity and autonomy but as the promise of a just social order. That body of thought is not all that far away from what it would take for Habermas to turn the European Union into a democratic federation: a measure of "civic solidarity" that "cannot develop if social inequalities between the member states become permanent structural features". The European Union therefore "must guarantee" an at least equitable degree of "social living conditions" (Habermas 2012: 53). The question is whether such living conditions can be achieved by mere fiscal redistribution, or whether social justice requires a federal form of civic solidarity in which the parameters of socioeconomic reproduction must be included in the question of what is particular and what can be universal and thus into the federal design itself.

\section{Federalism and democracy: a postscript}

Most likely because its complexities do not sit well with the assumptions of modern rationality, federalism is not often evaluated as a normative proposition. It is more typically scrutinized through the lens of democracy, which appears to satisfy the linearity of this rationality more easily: sovereign people, accountable government, majority rule. This is, of course, but a caricature of the many and far more advanced sophistications of democratic theory. As a caricature, however, it serves to highlight that the messy complexities of really existing federalism often get critically evaluated by a rather naive form of democratic idealism.

As Kincaid observed some time ago, it is modern democracy that is "inconceivable without competition" (1991: 97). Competition protects liberty insofar as it provides opposition and alternative to majority rule. The main safeguard for liberty in modern democracies has been party competition, and party competition in modern democracies has been fueled largely by class struggle. In the words of Machiavelli: "There are two different dispositions, that of the populace and that of the upper class and ... all legislation favorable to liberty is brought about by the clash between them" (1531/2 [1970], I: 4).

Class struggle embedded in party competition built the modern democratic welfare states. This form of democratic competition has largely fallen by the wayside under the hegemonic impact of the market-driven neoliberal TINA (There Is No Alternative) ideology. Democracy falters when political parties no longer offer competing visions of politics, and liberty falters when the disaffected begin to rally around populist leaders (Streeck 2017). While democracy is the aspirational end 
point of all political legitimacy, it is greatly overrated in practice, particularly so as a critical yardstick for the evaluation of complex political systems such as federalism.

In fact, the ultimate response to the question about a suitable research agenda for federalism and political theory is to take federalism more seriously as a normative proposition of political legitimacy in its own right. It would seem that the idea and tradition of a non-unitary form of political order grounded in principles of territorial identity, particular autonomy, membership equality and social solidarity, provide a promising reservoir of possibilities for what at least some expect to be a postmodern age and politics of difference (Young 1990). Maybe it is time to scrutinize democracy through the lens of federalism.

\section{NOTE}

1 This chapter will not deal with non-territorial forms of federalism that have been proposed and conceptualized on occasion (e.g., Nimni 2005).

\section{References}

Agranoff, Robert (ed.) (1999), Accommodating Asymmetry, Baden-Baden: Nomos.

Althusius, Johannes (1614 [1995]), Politica, Indianapolis, IN: Liberty Fund.

Amato, Giuliano (2002), "Plenary Speech", in Raoul Blindenbacher and Arnold Koller (eds), Federalism in a Changing World, Montreal: McGill-Queen's University Press.

Aristotle (1962), The Politics, London: Penguin.

Bakvis, Herman and Grace Skogstad (2012), Canadian Federalism, Don Mills: Oxford University Press.

Basta, Karlo, John McGarry and Richard Simeon (eds) (2015), Territorial Pluralism, Vancouver: University of British Columbia Press.

Bednar, Jenna (2009), The Robust Federation, New York: Cambridge University Press.

Béland, Daniel and André Lecours (2013), "Federalism, Nationalist Politics, and Social Policy: How Ideas and Institutions Shape Federal Dynamics", in Arthur Benz and Jörg Broschek (eds), Federal Dynamics, Oxford: Oxford University Press, pp. 577-81.

Blöchlinger, Hansjörg and Claire Charbit (2008), "Fiscal Equalization”, OECD Economic Studies, 44: 1.

Bodin, Jean (1583 [1992]), On Sovereignty, Cambridge: Cambridge University Press.

Breton, Albert (1987), "Towards a Theory of Competitive Federalism", European Journal of Political Economy, 3 (1+2), 263-329.

Broschek, Jörg (2013), "Between Path Dependence and Gradual Change: Historical Institutionalism and the Study of Federal Dynamics", in Arthur Benz and Jörg Broschek (eds), Federal Dynamics, Oxford: Oxford University Press, pp. 93-116.

Brouillet, Eugénie (2011), "Canadian Federalism and the Principle of Subsidiarity: Should We Open Pandora's Box?", Supreme Court Law Review, 54 (2d), 601-32.

Burgess, Michael (2006), Comparative Federalism: Theory and Practice, London: Routledge.

De Schutter, Helder (2011), "Federalism as Fairness", The Journal of Political Philosophy, 19 (2), 167-89.

Descartes, René (1637 [1985]), "Discourse on the Method”, in The Philosophical Writings of Descartes, volume 1, Cambridge: Cambridge University Press.

Dryzek, John S., Bonnie Honig and Anne Phillips (eds) (2006), The Oxford Handbook of Political Theory, Oxford: Oxford University Press. 
Elazar, Daniel J. (1987), Exploring Federalism, Tuscaloosa, AL: University of Alabama Press.

Elazar, Daniel J. and John Kincaid (eds) (200o), The Covenant Connection, Lanham, MD: Lexington Books.

Erk, Jan (2008), Explaining Federalism, London: Routledge.

Feeley, Malcolm and Edward L. Rubin (2008), Federalism: Political Identity and Tragic Compromise, Ann Arbor, MI: University of Michigan Press.

Fleming, James E. and Jacob T. Levy (eds) (2014), Federalism and Subsidiarity, Nomos LV, New York: New York University Press.

Habermas, Jürgen (1991), Theorie des kommunikativen Handelns, volume 2, Frankfurt: Suhrkamp.

Habermas, Jürgen (2012), The Crisis of the European Union, Cambridge: Polity Press.

Hall, Peter A. (2013), "Anatomy of the Euro Crisis", Harvard Magazine (November-December), accessed at http://harvardmagazine.com/2013/o7/anatomy-of-the-euro-crisis.

Hobbes, Thomas (1651 [1991]), Leviathan, Cambridge: Cambridge University Press, pp. 27-47.

Hooghe, Liesbet and Gary Marks (2003), "Unraveling the Central State but How? Types of Multi-Level Governance”, American Political Science Review, 97 (2), 233-43.

Hueglin, Thomas O. (1999), Early Modern Concepts for a Late Modern World, Waterloo: Wilfrid Laurier University Press.

Hueglin, Thomas O. (2013), “Comparing Federalisms: Variations or Distinct Models?”, in Arthur Benz and Jörg Broschek (eds), Federal Dynamics, Oxford: Oxford University Press, pp. 27-47.

Hueglin, Thomas O. and Alan Fenna (2015), Comparative Federalism, Toronto: University of Toronto Press.

Jerusalem, Franz (1949), Die Staatsidee des Föderalismus, Tübingen: Mohr.

Karmis, Dimitrios and Wayne Norman (eds) (2005), Theories of Federalism, New York: Palgrave.

Kincaid, John (1991), “The Competitive Challenge to Cooperative Federalism: A Theory of Federal Democracy", in Daphne A. Kenyon and John Kincaid (eds), Competition Among States and Local Governments, Washington, DC: The Urban Institute Press, pp. 87-114.

Kymlicka, Will (2005), "Federalism, Nationalism, and Multiculturalism", in Dimitrios Karmis and Wayne Norman (eds), Theories of Federalism, New York: Palgrave, pp. 269-92.

Levy, Jacob T. (2008), "Self-Determination, Non-Domination, and Federalism”, Hypatia, 23 (3), 60-78.

Lijphart, Arend (2012), Patterns of Democracy, New Haven, CT: Yale University Press.

Lindahl, Hans (2008), "Democracy, Political Reflexivity and Bounded Dialogues: Reconsidering the Monism-Pluralism Debate", in Emilios Christodoulidis and Stephen Tierney (eds), Public Law and Politics: The Scope and Limits of Constitutionalism, Aldershot: Ashgate, pp. 103-15.

Locke, John (1691 [1960]), Two Treatises of Government, Cambridge: Cambridge University Press.

Machiavelli, Niccolò (1531/2 [1970]), The Discourses, London: Penguin.

Marc, Alexandre (1979), "New and Old Federalism: Faithful to the Origins", Publius: The Journal of Federalism, 9 (4), 117-30.

Moore, Margaret (2015), A Political Theory of Territory, Oxford: Oxford University Press.

Neumann, Franz L. (1955), "Federalism and Freedom: A Critique”, in Arthur W. Macmahon (ed.), Federalism: Mature and Emergent, Garden City: Doubleday, pp. 44-57.

Neyer, Jürgen (2003), "Discourse and Order in the EU: A Deliberative Approach to Multi-Level Governance", Journal of Common Market Studies, 41 (4), 687-706.

Nimni, Ephraim (ed.) (2005), National-Cultural Autonomy and its Contemporary Critics, London: Routledge.

Pelletier, Benoît (2012), “The Future of Quebec Within the Canadian Federation”, in Alain-G. Gagnon (ed.), Contemporary Canadian Federalism, Toronto: University of Toronto Press, pp. 469-82.

Peterson, John (1996), “Subsidiarity: A Definition to Suit any Vision?”, Parliamentary Affairs, 47 (1), 117-32.

Proudhon, Pierre-Joseph (1863 [1979]), The Principle of Federation, Toronto: University of Toronto Press. 
Rawls, John (1971), A Theory of Justice, Cambridge, MA: Harvard University Press.

Riker, William H. (1955), “The Senate and American Federalism”, American Political Science Review, 49

(2), 452-69.

Riker, William H. (1964), Federalism: Origin, Operation, Significance, Boston, MA: Little, Brown.

Rodden, Jonathan A. (2006), Hamilton's Paradox, New York: Cambridge University Press.

Roemheld, Lutz (1990), Integral Federalism, New York: Peter Lang.

Rousseau, Jean-Jacques (1762 [1968]), The Social Contract, London: Penguin.

Sandel, Michael (1982), Liberalism and the Limits of Justice, Cambridge: Cambridge University Press.

Stepan, Alfred (1999), "Federalism and Democracy: Beyond the U.S. Model”, Journal of Democracy, 10 (4), 19-34.

Streeck, Wolfgang (2017), "The Return of the Repressed", New Left Review, 104, 5-18.

Tassin, Étienne (1992), "Europe: A Political Community?", in Chantal Mouffe (ed.), Dimensions of Radical Democracy, London: Verso, pp. 169-92.

The Federalist (1787/8 [2001]), Indianapolis, IN: Liberty Fund.

Thucydides (n.d. [1934]), Peloponnesian War, New York: Modern Library.

Ward, Ann and Lee Ward (2009), The Ashgate Research Companion to Federalism, Farnham: Ashgate.

Weinstock, Daniel (2001), "Towards a Normative Theory of Federalism", International Social Science Journal, 53 (167), 75-83.

Young, Iris Marion (1990), Justice and the Politics of Difference, Princeton, NJ: Princeton University Press.

Zheng, Yongnian (2007), De Facto Federalism in China, Singapore: World Scientific Publishing. 